\title{
Research on Industrial Cluster Development of Liaoning Coastal Economic Belt
}

\author{
Le Wang ${ }^{\mathrm{a}^{*}}$, Xuan Wu $\mathrm{u}^{\mathrm{b}}$ and Qingman $\mathrm{Li}^{\mathrm{c}}$ \\ Bohai University, Jinzhou, Liaoning, China

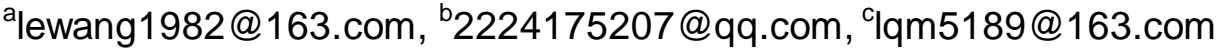

Keywords: Industrial cluster; Petrifaction industry; Equipment manufacturing industry; Key enterprises; Liaoning coastal economic belt

\begin{abstract}
Since 2009, the development and construction of Liaoning coastal economic belt has been included in the national development strategy, the industrial clusters in Liaoning six coastal cities has made rapid development. Up to now, six coastal cities have a total of 43 provincial key industrial clusters, mainly involves petrochemical industrial clusters, general equipment manufacturing industry clusters, marine engineering equipment manufacturing industry clusters, automobile and auto parts industry clusters, electronic information industry clusters, metallurgy and new materials industry clusters, agricultural product deeply processing industry clusters, photovoltaic and new energy industry clusters, garment and swimsuit industry clusters. These industrial clusters have greatly promoted the local economic growth and increased employment, but most of the industrial clusters are still small, industrial correlation is relatively poor, industrial isomorphism is relatively serious, industry level is low and lack of technological innovation. Liaoning coastal economic belt should develop leader enterprises, foster the innovative chain, and develop high and new technology industries and strategic emerging industries.
\end{abstract}

\section{Introduction}

Liaoning coastal economic belt is located in the coastal areas of Liaoning province, consists of 6 cities: Dalian, Dandong, Jinzhou, Yingkou, Panjin and Huludao (Fig. 1). In July 2009, The State Council approved the "Liaoning Coastal Economic Belt Development Plan", the development and construction of Liaoning coastal economic belt has been included in the national development strategy. ${ }^{[1]}$

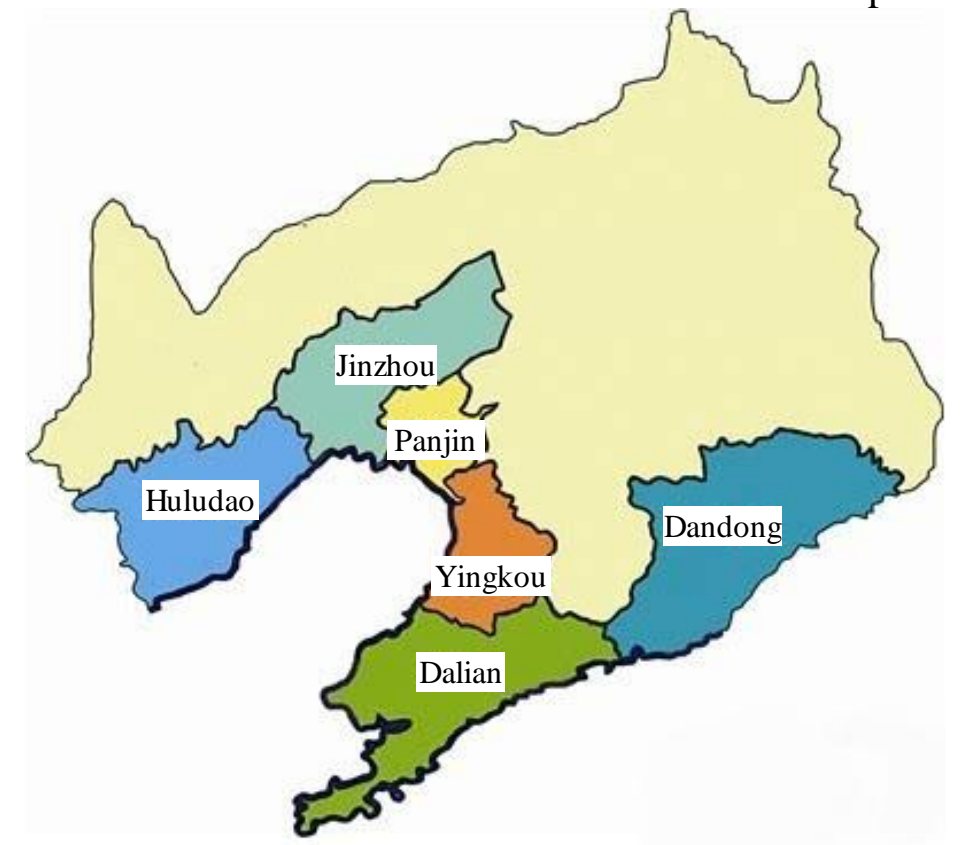

Figure 1. The location of Liaoning coastal economic belt

Industrial cluster plays an important role in promoting regional economic development and improving regional core competition. ${ }^{[2-9]}$ In order to expand the strategic adjustment of economic 
structure, cultivate new economic growth points, improve the industrial competitiveness, Liaoning provincial government issued the "several opinions on further promoting the development of industrial cluster" in 2011. Up to now, six coastal cities have a total of 43 provincial key industrial clusters. ${ }^{[10]}$ The distribution of key industrial clusters and sales revenue in 2015 is shown in Table 1.

Table 1 Distribution of key industrial clusters in Liaoning coastal economic belt

\begin{tabular}{|l|c|c|}
\hline City & Number of Key Industrial Clusters & $\begin{array}{c}\text { Total Sales Revenue in 2015 } \\
\text { (Billion yuan) }\end{array}$ \\
\hline Dalian & 19 & 646.2 \\
\hline Panjin & 4 & 163.3 \\
\hline Yingkou & 4 & 144.9 \\
\hline Jinzhou & 5 & 117.7 \\
\hline Huludao & 6 & 59 \\
\hline Dandong & 5 & 37 \\
\hline Total & 43 & 1168.1 \\
\hline
\end{tabular}

\section{The Development of Key Industrial Clusters of Liaoning Coastal Economic Belt}

Dalian City. The nineteen key industrial clusters are mainly located in Dalian High-tech Zone, Jinpu New Area, Lushun, Wafangdian and Zhuanghe, mainly involve petrochemical industry, aromatic hydrocarbon, general equipment manufacturing industry, automobile and auto parts industry, electronic information industry and others (Table 2). Main products include fine chemicals, general equipment and special equipment, automobile and auto parts, engine, software and information services, semiconductor integrated circuit, metallic materials, new materials, agricultural products, furniture and medical equipment.

Table 2 Key industrial clusters of Dalian City

\begin{tabular}{|l|l|c|}
\hline Industrial Cluster Name & Key Enterprises & $\begin{array}{l}\text { Sales Revenue in } \\
\text { 2015 (Billion yuan) }\end{array}$ \\
\hline Dalian software and services & IBM, HP, Dell, Neusoft, Huaxin & 105.1 \\
\hline Jinzhou equipment manufacturing & Dalian Insulator, Matsushita, SKF & 85.3 \\
\hline Jinzhou auto parts & Volkswagen, Deutz, Thyssen Krupp & 35.0 \\
\hline Jinzhou electronic information & Intel, Rohm, TDK, OMRON, Alpine & 31.9 \\
\hline Jinzhou biomedical & Pfizer, Zhenao, Yalifeng, Innobio & 16.3 \\
\hline Dagushan petrochemical & West Pacific, Fujia, Yisheng, Kaifei & 58.6 \\
\hline Dalian Dengshahe steel & Donbei Special Steel, Huicheng Al & 17.0 \\
\hline Changxing Island petrochemical & PetroChina, Hengli Petrochemical & 19.0 \\
\hline Coastal equipment manufacturing & COSCO, CFHI, China Shipbuilding & 38.7 \\
\hline Lushun ship supporting & COSCO Shipbuilding, Jinjia Ship & 11.5 \\
\hline Huayuankou new material & BYD, BAK, HG Lithium, JM Boron & 10.3 \\
\hline Songmu Island chemical & Dahua Group, Pride chemistry & 14.5 \\
\hline Dalian automobile & Dongfeng-Nissan, Chery, Brilliance & 11.1 \\
\hline Zhuanghe agricultural products & Shandao, Fugu, Shangpintang & 41.7 \\
\hline Zhuanghe machine tool & Huafeng, Huaxia, Wanpeng, Kemain & 45.4 \\
\hline Zhuanghe furniture & Donghao, Boda, Zhuoyuan, Baihui & 17.3 \\
\hline Wafangdian bearing & Wafangdian bearing, Yuandong Bearing & 50.4 \\
\hline Dalian garment & TRANDS, PARKLAND, Xincheng & 29.1 \\
\hline Pulandian power equipment & Dalian Mutual Inductor, North MI & 8.0 \\
\hline
\end{tabular}

Panjin City. The four key industrial clusters are mainly located in Panjin High-tech Zone, Liaodong Bay Area, Panjin Fine Chemical Industrial Park, mainly involve fine chemical industry, petroleum 
equipment industry, plastic industry and marine engineering equipment manufacturing (Table 3). Main products include methyl tert butyl ether, asphalt and rubber, lubricating oil, drilling rig, offshore drilling platform, special ship and plastic film.

Table 3 Key industrial clusters of Panjin City

\begin{tabular}{|l|l|c|}
\hline Industrial Cluster Name & Key Enterprises & $\begin{array}{l}\text { Sales Revenue in } \\
\text { 2015 (Billion yuan) }\end{array}$ \\
\hline Petrochemical and fine chemical industry & North Huajin Chemical, CCP & 101.5 \\
\hline Petroleum equipment manufacturing & CPLEC, Pipe Drill, Tianyi Petro & 34.1 \\
\hline Marine equipment manufacturing & ZW Aluminum, Liaohe Heavy & 4.9 \\
\hline Plastics and new materials & Jintian Plastic, Shengyou Rubber & 22.8 \\
\hline
\end{tabular}

Yingkou City. The four key industrial clusters are mainly located in Bayuquan District, Dashiqiao and Xianren Island, mainly involve metal processing industry, petrochemical industry and automobile maintenance equipment industry (Table 4). Main products include magnesium products, iron and steel products, asphalt and plastic products, automobile lifting machine, and tire dynamic balance instrument.

Table 4 Key industrial clusters of Yingkou City

\begin{tabular}{|l|l|c|}
\hline Industrial Cluster Name & Key Enterprises & $\begin{array}{l}\text { Sales Revenue in } \\
\text { 2015 (Billion yuan) }\end{array}$ \\
\hline Magnesium products and processing & Qinghua Group, Jinlong, Qunyi & 83.4 \\
\hline Bayuquan iron and steel & Anshan Steel, North Steel Pipe & 20.3 \\
\hline Xianren Island petrochemical & CNOOC Asphalt, Kanghui Petro & 24.6 \\
\hline Automobile maintenance equipment & Taida Automobile Maintenance & 16.6 \\
\hline
\end{tabular}

Jinzhou City. The five key industrial clusters are mainly located in Jinzhou Binhai New Area, Linghai and Yixian, mainly involve photovoltaic and new energy industry, petrochemical and fine chemical industry, special metal industry, automobile and auto parts industry, and metallurgical materials industry (Table 5). Main products include industrial silicon, polycrystalline silicon, monocrystalline silicon, silicon wafer, solar cell, vehicle fuel oil, isopropyl alcohol, lubricating oil additive, rubber, propane, aromatic hydrocarbon, titanium dioxide, silicon manganese, molybdenum chemical products, automobile electrical appliance, suspension, air bag, container, coke, silicon and manganese alloy and ductile iron pipes.

Table 5 Key industrial clusters of Jinzhou City

\begin{tabular}{|l|l|c|}
\hline Industrial Cluster Name & Key Enterprises & $\begin{array}{c}\text { Sales Revenue in } \\
2015 \text { (Billion yuan) }\end{array}$ \\
\hline Photovoltaic and new energy & Solar Energy, Boyang Photovoltaic & 15.3 \\
\hline Petrochemical and fine chemical & PetroChina, Jiahe, Tianhe, Heisenberg & 45.7 \\
\hline Titanium and special metal & CITIC, Baoti, Xinhualong Molybdenum & 16.0 \\
\hline Automobile and auto parts & Wonder Auto, Hanna, Oriental Container & 23.4 \\
\hline Metallurgical materials & Fengan, Yuehua Marine, Raoxin Elly & 17.3 \\
\hline
\end{tabular}

Huludao City. The six key industrial clusters are mainly located in Huludao Northport Industrial Park, Huludao High-tech Zone, Xingcheng, and East Daihe, mainly involve petrochemical industry, swimsuit industry, marine equipment industry, molybdenum processing industry, valve industry and digital technology industry (Table 6). Main products include polyurethane, swimsuit and fabrics, marine engineering equipment, molybdenum concentrate, nonferrous metal, fluid machinery and valves, IT products and high-tech digital products. 
Table 6 Key industrial clusters of Huludao City

\begin{tabular}{|l|l|c|}
\hline Industrial Cluster Name & Key Enterprises & $\begin{array}{c}\text { Sales Revenue in } \\
2015 \text { (Billion yuan) }\end{array}$ \\
\hline Polyurethane petrochemical & PetroChina, Fangda Chemical, CNOOC & 40 \\
\hline Swimsuit and fabrics & Jiulong, Tiancheng, Xiadie, Yilang, Sanqi & 15 \\
\hline Marine engineering equipment & Bohai Shipbuilding, Dongbao, Jiangzhe & 14 \\
\hline Molybdenum deep processing & Wonder Auto, Hanna, Oriental Container & 3 \\
\hline Pumps and valves & Lianshan Molybdenum, MCC, HLD Zinc & 0.5 \\
\hline Digital technology & Guoxing Tech, Legu Soft, Ninestar Tech & 1.5 \\
\hline
\end{tabular}

Dandong City. The five key industrial clusters are mainly located in Dandong Harbor Industrial Park, Dandong High-tech Zone, Fengcheng and Kuandian, mainly involve automobile and auto parts industry, instrumentation industry, protective textile industry, Manchu medicine and health industry (Table 7). Main products include large and medium bus, SUV, special vehicle, auto parts, booster, automation and control instruments, scientific instruments, protective textile, medical instruments and Manchu medicine.

Table 7 Key industrial clusters of Dandong City

\begin{tabular}{|l|l|c|}
\hline Industrial Cluster Name & Key Enterprises & $\begin{array}{c}\text { Sales Revenue in } \\
\text { 2015 (Billion yuan) }\end{array}$ \\
\hline Automobile and auto parts & SG Automotive Group, 518 Engine Parts & 12 \\
\hline Instrumentation & Dongfa, Oriental Controlling, Huari, Aolong & 7.5 \\
\hline Protective textile & Star Fine Chemicals, Huaxing Textiles & 7 \\
\hline Fengcheng auto booster & Shenlong, Oriental, Phoenix, Green Booster & 6 \\
\hline Manchu medicine and health & Dandong Pharmaceutical, Kangchen PHA & 4.5 \\
\hline
\end{tabular}

The Main Achievements. In 2015, 34 of the 43 key industrial clusters' sales revenue are over 10 billion yuan. 6 industrial clusters of Dalian City have been identified as the national new industrialization demonstration base, Dalian software and outsourcing services industrial cluster is the first cluster that reached 100 billion yuan in China software industry. Dandong instrumentation industrial cluster is one of the three major production bases in China, Fengcheng auto booster production accounted for 1/4 of China. Dashiqiao was named "China magnesium capital". Panjin petrochemical and fine chemical industry is the first cluster that reached 100 billion yuan in Liaoning province. Huludao swimsuit network sales accounted for about $70 \%$ of the country. In short, these industrial clusters have greatly promoted the local economic growth, increased employment, and promoted the regional competitiveness.

\section{The Main Problems of Key Industrial Clusters of Liaoning Coastal Economic Belt}

Scales of Industrial Clusters Are Still Small. In 2015, only two key industrial clusters' sales revenue are over 100 billion yuan, nine key industrial clusters' sales revenue are less than 10 billion yuan. The average of sales revenue of Dandong key clusters is only 7.4 billion yuan. Huludao pumps and valves industrial cluster's sales revenue is only 0.5 billion yuan.

Industrial Correlation Is Relatively Poor. Some clusters are only the same link in the industrial chain, industrial chain is short. Some clusters have less communication and interaction, the upstream and downstream supporting relationship is not strong, the effect of industrial agglomeration is not fully demonstrated.

Industrial Isomorphism Is Serious. Six coastal cities have an obvious industrial isomorphism, Petrochemical industrial clusters are developed in Dalian, Panjin, Jinzhou and Huludao; metallurgical industrial clusters are developed in Dalian, Yingkou, Jinzhou and Huludao; automobile and auto parts 
industrial clusters are developed in Dalian Dandong, Jinzhou and Yingko; equipment manufacturing industrial cluster are developed in Dalian, Panjin and Huludao.

Industrial Level Is Low. Petrochemical, metallurgy, machinery manufacturing and other traditional industries still dominates, seriously affected the quality of environment. The proportion of emerging industries (such as energy saving and environmental protection, information industry, bio industry, new energy, new energy vehicles, high-end equipment manufacturing and new materials) is still very low.

Lack of Technological Innovation. Most of the industry is still in the low end of the industrial chain, produced low value-added products, independent innovation capability is limited. Some enterprises don't want to innovative technologies, and don't have the strategic awareness and sense of crisis.

\section{Countermeasure and Suggestions}

Develop Leading Enterprise. Select the key enterprises that with high technological ability, strong market competitiveness and leading role of industry as the leading enterprises. Support the technological innovation, brand cultivation and market expansion, make these leading enterprises become the core power of industrial technology innovation.

Build the Industrial Chain and Foster the Innovation Chain. Investment needs to focus on the industrial chain, and avoid new overcapacity. Cultivate the innovation chain composed of a variety of innovative activities, including knowledge creation and transfer, generic technology development and service, system integration technology research and development, engineering innovation, innovation support and industrialization service.

Strictly Control Industrial Isomorphism. Deeply investigate the key industries in the six coastal cities, evaluate the similarity and relevance, analyze the relationship between technical structure and product supply and demand, build cross industry and cross regional industrial chain, strictly control industrial isomorphism, and achieve coordinated development.

Develop High-tech Industries and Strategic Emerging Industries. Based on existing industry and resources, put priority on the development of advanced equipment manufacturing in Dalian, new plastic materials in Panjin, metal processing in Yingou, photovoltaic and new energy in Jinzhou, marine engineering equipment in Huludao, and Manchu medicine in Dandong, and pay more attention to the "high" and "new".

Promote the Transformation and Upgrading of Liaoning Coastal Cities Based on Innovation Driven. Liaoning provincial government should carry out the top-level design of Liaoning innovation driven development, accelerate reform of institutions and mechanisms, increase motivation for pursuing innovation-driven development, establish a new system for developing modern industries, and create new favorable conditions for developing the open economy.

\section{Acknowledgements}

This research was supported by the MOE (Ministry of Education in China) Project of Humanities and Social Sciences (Project No. 16YJC630120, "Research on supply chain collaborative innovation mechanism and incentive mechanism of new energy industry cluster: from the perspective of vertical market structure").

\section{References}

[1] Y. Xiang, T. Wen, Y. Liu: American Journal of Industrial \& Business Management, Vol.2 (2012) No.1, p.13-15.

[2] E. Barbieri, M.R.D. Tommaso, S. Bonnini: China Economic Review, Vol.23 (2012) No.3, p.613-625.

[3] S. Novani, U.S. Putro, P. Hermawan: Procedia - Social and Behavioral Sciences, Vol.169 (2015) p.207-216. 
[4] Z. Wang, Y. Zhang: International Journal of Business Administration, Vol.6 (2015) No.3.

[5] S. Cai, W. Liao: Reformation \& Strategy, Vol.26 (2012) No.9, p.1603-1612.

[6] Y.L. Chyi, Y.M. Lai, W.H. Liu: Research Policy, Vol.41 (2012) No3, p.953.

[7] H.L. Costa, H.L. Costa, A.L.V. Torkomian: International Journal of Technology Management \& Sustainable Development, Vol.14 (2015) No.2, p.125-139.

[8] O. Toshihiro, O. Tetsuji: Japanese Journal of Applied Physics, Vol.50 (2015) No.11.

[9] K. Heavner, C.A. Grossdavis, A.L. Frank, C. Newschaffer, J. Klotz: American Journal of Industrial Medicine, Vol.58 (2015) No.6, p.595-604.

[10] H. Yu, M. Jiang, C. Li: Modern Physics Letters B, Vol.30 (2016) No.8, p.165. 